\begin{tabular}{|c|c|}
\hline Title & $\begin{array}{l}\text { A novel anticancer ribonucleoside, 1-(3-C-ethynyl- } \beta \text {-D-ribo-pentofuranosyl)cytosine, enhances radiation-induced cell } \\
\text { death in tumor cells. }\end{array}$ \\
\hline Author(s) & $\begin{array}{l}\text { Inanami, O samu; Iizuka, Dai suke; I wahara, A kiko; Y amamori, T ohru; Kon, Y asuhiro; A sanuma, T aketoshi; Matsuda, } \\
\text { A kira; Kashiwakura, I kuo; Kitazato, Kenji; Kuwabara, Mikinori }\end{array}$ \\
\hline Citation & $\begin{array}{l}\text { Radiation Research, 162(6), 635-645 } \\
\text { https://doi.org/10.1667/RR3268 }\end{array}$ \\
\hline Issue Date & $2004-12$ \\
\hline Doc URL & http:/hdl .handle.net/2115/27978 \\
\hline Tyре & article \\
\hline File Information & RR162-6.pdf \\
\hline
\end{tabular}

Instructions for use 


\title{
A Novel Anticancer Ribonucleoside, 1-(3-C-Ethynyl- $\beta$-D-ribo-pentofuranosyl)Cytosine, Enhances Radiation-Induced Cell Death in Tumor Cells
}

\author{
Osamu Inanami, ${ }^{a}$ Daisuke Iizuka, ${ }^{a}$ Akiko Iwahara, ${ }^{a}$ Tohru Yamamori, ${ }^{a}$ Yasuhiro Kon, ${ }^{b}$ Taketoshi Asanuma, ${ }^{a}$ \\ Akira Matsuda, ${ }^{c}$ Ikuo Kashiwakura, ${ }^{d}$ Kenji Kitazato $^{e}$ and Mikinori Kuwabara ${ }^{a, 1}$

\begin{abstract}
${ }^{a}$ Laboratory of Radiation Biology and ${ }^{b}$ Laboratory of Anatomy, Graduate School of Veterinary Medicine, Hokkaido University, Sapporo 060-0818, Japan; ' Laboratory of Medicinal Chemistry, Graduate School of Pharmaceutical Sciences, Hokkaido University, Sapporo 060-0812, Japan; ${ }^{d}$ Department of Radiological Technology, Hirosaki University School of Health Sciences, Hirosaki 036-8564, Japan; and e Cancer Research
\end{abstract} \\ Laboratory, Hanno Research Center, Taiho Pharmaceutical Co., Ltd., Saitama 357-8527, Japan
}

Inanami, O., Iizuka, D., Iwahara, A., Yamamori, T., Kon, Y., Asanuma, T., Matsuda, A., Kashiwakura, I., Kitazato, K. and Kuwabara, M. A Novel Anticancer Ribonucleoside, 1-(3C-Ethynyl- $\beta$-D-ribo-pentofuranosyl)Cytosine, Enhances Radiation-Induced Cell Death in Tumor Cells. Radiat. Res. 162, 635-645 (2004).

1-(3-C-Ethynyl- $\beta$-D-ribo-pentofuranosyl)cytosine (ECyd, TAS106) is a newly developed anti-tumor agent that targets RNA synthesis. We report here that a low dose of ECyd induces radiosensitization of caspase-dependent apoptosis and reproductive cell death in cells of the gastric tumor cell lines MKN45 and MKN28 and murine rectum adenocarcinoma Colon26. Flow cytometry demonstrated that TAS106 induced the abrogation of the $X$-ray-induced $G_{2} / M$ checkpoint. Western blot analysis showed that $X$ rays increased the expression of cyclin B1, phospho-Cdc2 and Wee1, whereas co-treatment with $X$ rays and TAS106 decreased the expression of these cell cycle proteins associated with the $G_{2} / M$ checkpoint. Furthermore, TAS106 was shown to decrease the radiation-induced expression of survivin but not $\mathrm{Bcl} 2$ and $\mathrm{BclX} \mathrm{L}_{\mathrm{L}}$ regardless of TP53 status and cell type. Overexpression of wild-type survivin in MKN45 cells inhibited the induction of apoptosis induced by co-treatment with $X$ rays and TAS106. These results suggest that TAS106 enhances X-ray-induced cell death through down-regulation of survivin and abrogation of the cell cycle machinery. @ 2004 by Radiation Research Society

\section{INTRODUCTION}

Ionizing radiation is known to cause cell cycle arrest in the $\mathrm{G}_{2} / \mathrm{M}$ phase as well as cell death. DNA double-strand breaks induced by radiation are recognized by ataxia telangiectasia mutated (ATM), which inhibits the passage of DNA-damaged cells from $\mathrm{G}_{2}$ into the $\mathrm{M}$ phase. ATM is

${ }^{1}$ Address for correspondence: Laboratory of Radiation Biology, Graduate School Veterinary Medicine, Hokkaido University, Sapporo 0600818, Japan; e-mail: kuwabara@vetmed.hokudai.ac.jp. required for the activation of Chk1/2 in response to DNA damage, followed by the phosphorylation of $\mathrm{Cdc} 25 \mathrm{C}$ phosphatase on Ser216. The phosphorylation of Cdc25C phosphatase creates a binding site for 14-3-3 proteins. The 143-3-bound phosphatase is then sequestered outside of the nucleus and cannot dephosphorylate and activate the mitosis-promoting Cdc2-cyclin B1 complex (1).

Abrogation of the $G_{2} / M$ checkpoint often leads to a marked increase in the sensitivity of cells to ionizing radiation and some types of chemotherapy. 7-Hydroxystaurosporine (UCN-01) has been reported to enhance the antitumor activities of mitomycin $\mathrm{C}(2)$ and ionizing radiation (3-6) by abrogating the $\mathrm{G}_{2} / \mathrm{M}$ checkpoint functions through the inhibition of a kinase presenting upstream of Cdc25C, Cdc2 and Wee1. An indolocarbazole inhibitor (SB-218078) against Chk1 was also reported to abrogate the $\mathrm{G}_{2} / \mathrm{M}$ arrest caused by $\gamma$-ray-induced or topotecan-induced DNA damage and to enhance apoptosis (7). Caffeine is also known to be a radiosensitizing agent $(8-10)$ that attenuates the radiation-induced $\mathrm{G}_{2} / \mathrm{M}$ checkpoint by inhibiting radiationinduced activation of ATM and ataxia telangiectasia mutated and Rad3-related (ATR) (10). Furthermore, abrogation of DNA damage-induced $S$ and $\mathrm{G}_{2} / \mathrm{M}$ checkpoints by antisense inhibition of Chk2 has been shown to enhance radiation-induced apoptosis in HEK-293 cells (11). These results suggest a strong relationship between radiosensitization and inhibition of the $\mathrm{G}_{2} / \mathrm{M}$ checkpoint in various tumor cell lines, irrespective of TP53 status. However, less is known about how abrogation of the $\mathrm{G}_{2} / \mathrm{M}$ checkpoint leads to apoptosis.

Survivin, which belongs to the inhibitors of apoptosis protein (IAP) family with a domain designated the baculovirus IAP repeat (BIR), has been found to be intensively expressed in the $\mathrm{G}_{2} / \mathrm{M}$ phase (12). Survivin is located in kinetochores of metaphase chromosomes and in the central spindle midzone in anaphase (13). Several reports have consistently shown that the overexpression of survivin inhibits cell death induced by various stimuli of apoptosis. 
Targeting experiments using an antisense oligodeoxyribonucleotide for survivin, a Thr34 $\rightarrow$ Ala or Cys84 $\rightarrow$ Ala dominant negative mutant induced the loss of the functions of survivin, followed by the enhancement of apoptosis induced by spontaneous or genotoxic stimuli or the inhibition of cell proliferation (14-20). This ability of survivin to inhibit apoptosis has been considered to be due to attenuation of the activities of caspases 3 and 7 by binding with the BIR domain of survivin $(21,22)$. Recently, survivin was reported to inhibit not only caspase-dependent apoptosis but also caspase-independent cell death as a result of mitotic catastrophe (23). Furthermore, it has been demonstrated that the cell cycle periodicity of survivin expression is controlled by a ubiquitin-dependent destruction system, and $>40$-fold up-regulated survivin is observed in the $\mathrm{G}_{2} / \mathrm{M}$ phase (24). Survivin undergoes cell cycle-dependent phosphorylation on Thr34 by a Cdc2-cyclin B1 complex, and the loss of this phosphorylation results in the dissociation of the survivin-caspase 3 complex on the mitotic apparatus and caspase 3-dependent apoptosis of cells traversing mitosis (17-19). On the other hand, phosphorylation of Bcl2, another anti-apoptosis protein, in $\mathrm{G}_{2} / \mathrm{M}$-phase-arrested cells after photodynamic therapy with hypericin involves a Cdc2-mediated signal and delays the onset of apoptosis (25). These experiments led us to assume that survivin or Bcl2 played a key role in the induction of apoptosis by abrogation of the DNA damage-induced $\mathrm{G}_{2} / \mathrm{M}$ checkpoint.

1-(3-C-Ethynyl- $\beta$-D-ribo-pentofuranosyl) cytosine (ECyd, TAS106) has recently been developed as a novel antitumor agent (26). TAS106 (ECyd) is rapidly phosphorylated to ECyd 5'-triphosphate (ECTP), which is essential for its cytotoxicity (26-31). The strong toxicity of ECTP for tumor cells is due to its inhibition of RNA synthesis. Because of the mechanism of action of TAS106, it is possible that a low dose of TAS106 would enhance radiationinduced apoptosis through the down-regulation of protein expression related to a cell cycle checkpoint or an antiapoptosis function. In this study, we investigated the effects of TAS106 on radiation-induced cell death and the $\mathrm{G}_{2} / \mathrm{M}$ checkpoint in gastric tumor cells and murine rectum tumor cells using a low dose of TAS106, which did not induce cell death itself.

\section{MATERIALS AND METHODS}

\section{Materials}

1-(3-C-Ethynyl- $\beta$-D-ribo-pentofuranosyl)cytosine (TAS106) was synthesized as described elsewhere (26). Antibodies against Cdc2, cyclin B1, Wee1, Bcl2, BclX $\mathrm{L}_{\mathrm{L}}$ and actin were purchased from Santa Cruz Biotechnology (Santa Cruz, CA). Antibodies against phospho-Cdc25 and phospho-Cdc2 were from Cell Signaling Technology Inc. (Beverly, MA), and the antibody against survivin was from Alpha Diagnostic International, Inc. (San Antonio, TX). Other reagents were purchased from Wako Chemical Co. (Osaka, Japan).

\section{Cell Culture and Treatment of TAS106 and X Irradiation}

Human gastric adenocarcinoma MKN45 (TP53 wild-type) and MKN28 (TP53 mutation) cells and murine rectum adenocarcinoma Colon26 cells were grown in monolayer cultures at $37^{\circ} \mathrm{C}$ in RPMI 1640 medium (Gibco-BRL/Invitrogen, Carlsbad, CA) supplemented with $10 \%$ fetal calf serum. The MKN45, MKN28 and Colon26 cells, which were pretreated with $0.1,1$ and $5 \mu M$ of TAS106, respectively, were irradiated with an X-ray generator $(2.0-\mathrm{mm}$ aluminum filter, $200 \mathrm{kVp}, 20 \mathrm{~mA}$, Shimadzu HF-320, Kyoto, Japan) at a dose of $3.03 \mathrm{~Gy} / \mathrm{min}$, which was determined using a Fricke chemical dosimeter. Cells $\left(1 \times 10^{6}\right.$ cells $\left./ \mathrm{ml}\right)$ were incubated in growth medium at $37^{\circ} \mathrm{C}$ for $1 \mathrm{~h}$ before $\mathrm{X}$ irradiation. For treatment with benzyloxycarbonyl-Val-Ala-Asp-fluoromethylketone (Z-VADfmk) (Peptide Institute, Tokyo, Japan), cells were incubated in growth medium with the inhibitor at $50 \mu M$ for $1 \mathrm{~h}$ before $\mathrm{X}$ irradiation.

\section{Fluorescence Microscopic Observation of Apoptotic Cells}

Cells $\left(5 \times 10^{5}\right)$ incubated for the indicated periods after $\mathrm{X}$ irradiation without or with drugs were collected by centrifugation at $1,000 \mathrm{rpm}$ for 5 min at $4{ }^{\circ} \mathrm{C}$. The pellet was washed in $\mathrm{Ca}^{2+}$ - and $\mathrm{Mg}^{2+}$-free phosphatebuffered saline $[\mathrm{PBS}(-)]$ and fixed with $1 \%$ glutaraldehyde/PBS(-) solution. For fluorescence microscopy, the fixed cells were washed and resuspended in $\operatorname{PBS}(-)$. An aliquot was stained with propidium iodide (Sigma Chemical, St. Louis, MO) in PBS(-) at $40 \mu \mathrm{g} / \mathrm{ml}$ for $15 \mathrm{~min}$ in the dark. The stained cells were placed on a microscope slide and gently covered with a cover slip. Fluorescence microscopic observation was performed using an Olympus BX50 microscope (Olympus, Tokyo, Japan) with reflected-light fluorescence $(32,33)$.

\section{Clonogenic Assay}

The MKN45, MKN28 and Colon26 cells, which were treated with 0.1, 0.5 and $0.5 \mu M$ of TAS 106 at $37^{\circ} \mathrm{C}$ for $1 \mathrm{~h}$, respectively, were irradiated with $\mathrm{X}$ rays at doses from 0 to $9 \mathrm{~Gy}$, and then 100 to 30,000 cells were seeded on $6-\mathrm{cm}$ petri dishes containing the medium with TAS106, followed by incubation at $37^{\circ} \mathrm{C}$ for $36 \mathrm{~h}$. After the medium was changed to fresh medium without TAS106, the cells were subsequently cultured. After 7 days, the cells were fixed with methanol and stained with Giemsa stain. Only colonies containing more than 50 cells were scored as surviving cells. After the surviving fraction at each dose was calculated with respect to the plating efficiency of the nonirradiated control, the doseresponse curves were plotted.

\section{Cloning of Survivin cDNA, Plasmid Construction and Expression}

Human survivin cDNA was obtained by reverse transcription-PCR of RNA derived from HeLa cells with the following primers based on GenBank accession number U75285 (forward, 5'-GCATGGGTGCCCC GACGTTG-3', reverse, 5'-GCTCCGGCCAGAGGCCTCAA-3'). PCR products were cloned into $\mathrm{pCR} 2.1 \mathrm{TOPO}$ vector using the TOPO TA cloning system according to the manufacturer's instructions (Gibco-BRL/ Invitrogen). Wild-type survivin cDNA was cloned into the EcoRI site of pCIneo expression vector (Clontech BD Biosciences, Palo Alto, CA). In transfection of the plasmid construction, LipofectAMINE Plus (Gibco$\mathrm{BRL} /$ Invitrogen) was used to transfect $0.4 \mu \mathrm{g}$ of $\mathrm{pCIneo-survivin} \mathrm{vector}$ and $0.1 \mu \mathrm{g}$ of pQBI-GFP vector (Nippon Gene, Tokyo, Japan) per 35$\mathrm{mm}$ dish of MKN45 cells $\left(1.5 \times 10^{5} /\right.$ dish $)$ according to the manufacturer's instructions. The cells transfected with the expression vector were incubated for $36 \mathrm{~h}$ after the treatment with TAS106 and/or X rays and then apoptosis and cell cycle status were examined by fluorescence microscopy and flow cytometry, respectively.

\section{Agarose Gel Electrophoresis for Apoptosis}

Cells $\left(2.0 \times 10^{7}\right)$ exposed to $\mathrm{X}$ rays and/or TAS106 for $36 \mathrm{~h}$ were collected by centrifugation at $1,000 \mathrm{rpm}$ for $5 \mathrm{~min}$ at $4^{\circ} \mathrm{C}$. The pellet was washed with PBS(-). DNA fragmentation assay was performed according to the method of Ramakrishnan and Catravas (34). Briefly, lysis buffer (0.2\% Triton X-100, $10 \mathrm{~m} M$ Tris-HCl, $\mathrm{pH} 7.5,10 \mathrm{~m} M$ EDTA) was added to the cell pellet followed by centrifugation at $15,000 \mathrm{rpm}$ for $30 \mathrm{~min}$ at $4^{\circ} \mathrm{C}$. DNA was extracted from the supernatant by phenol:chloroform:isoa- 
A

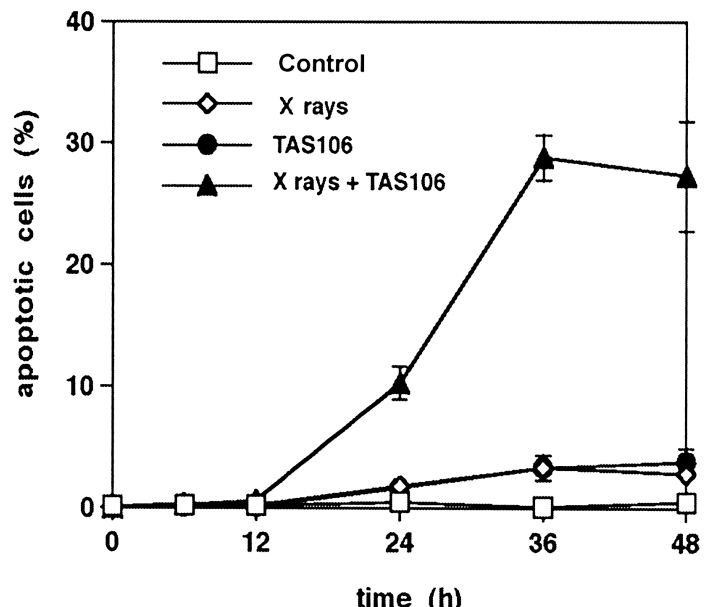

B
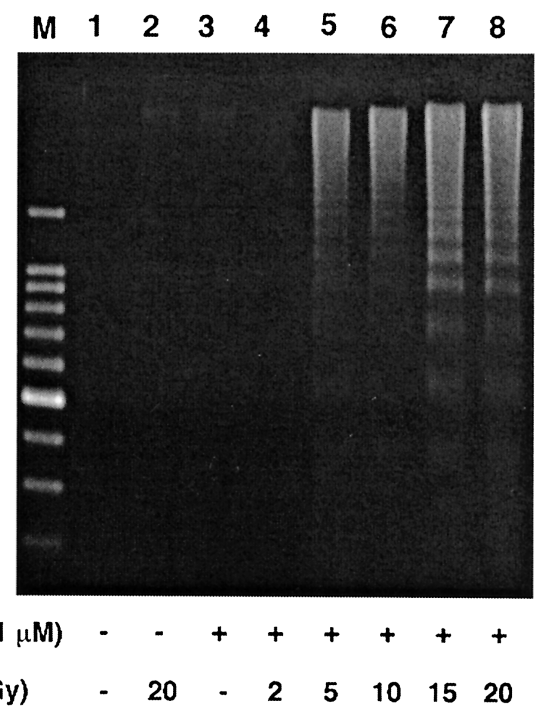

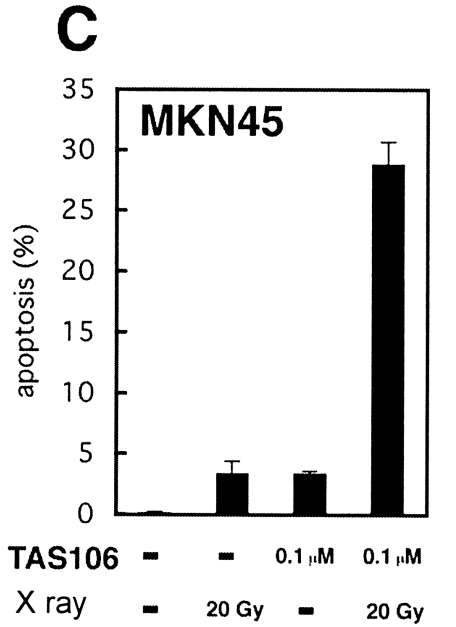

$\mathbf{F}$

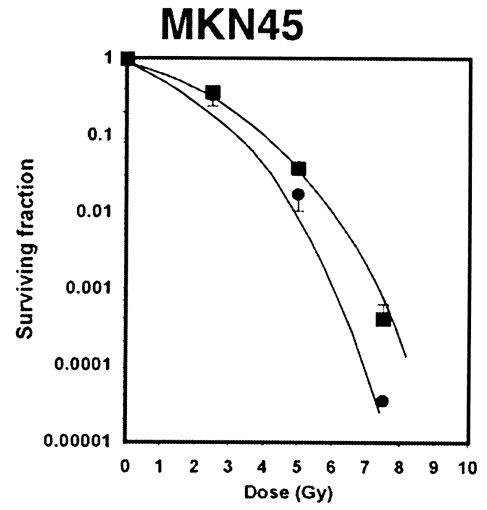

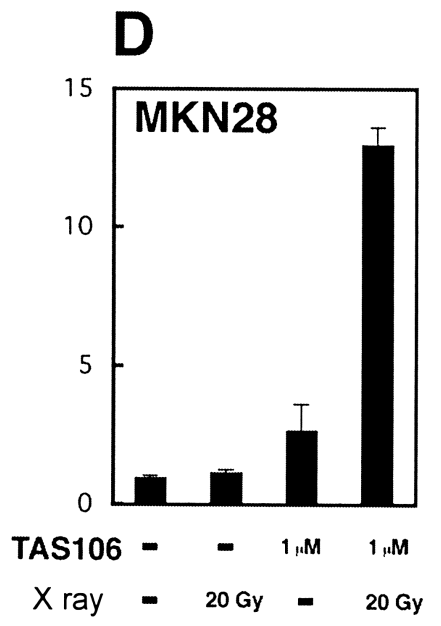

G

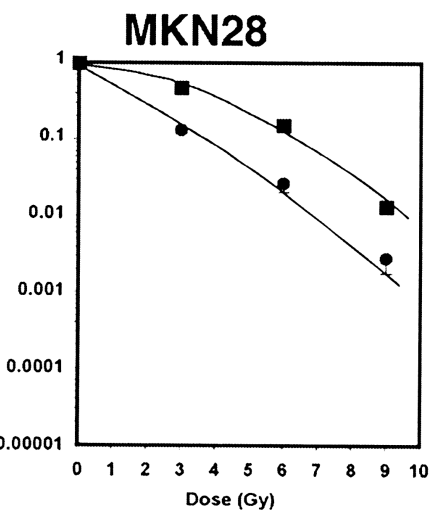

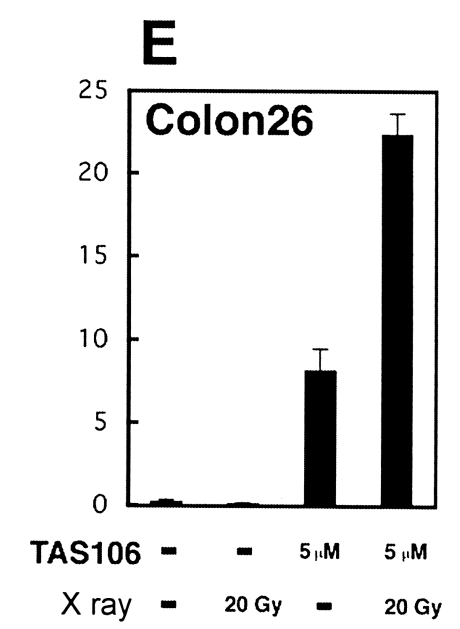

$\mathrm{H}$

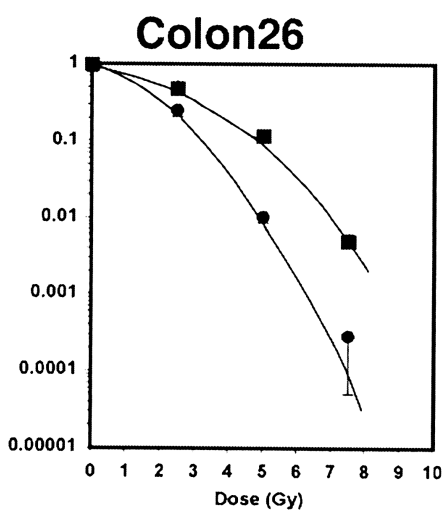

FIG. 1. TAS106 enhances X-ray-induced apoptosis and reproductive death in MKN45, MKN28 and Colon26 cells. Panel A: KN45 cells treated with $0.1 \mu M$ TAS106, 20 Gy X rays, or X rays $(20$ Gy) + TAS106 $(0.1 \mu M)$ were incubated for several hours. Cells were collected at the indicated times and stained with propidium iodide after fixation. At least 200 cells were scored for each determination for apoptotic cells. Panel B: DNA fragmentation was measured $48 \mathrm{~h}$ after treatment with various doses of X rays in the presence of TAS106. Panels C and D: Radiosensitization of apoptosis and abrogation of the $\mathrm{G}_{2} / \mathrm{M}$ checkpoint by TAS106 irrespective of TP53 status and cell line. After treatment with TAS106, X rays or X rays + TAS106, cells were collected at $48 \mathrm{~h}$ for MKN45 cells (panel C), $24 \mathrm{~h}$ for MKN28 cells (panel D), and $36 \mathrm{~h}$ for Colon26 (panel E) and stained with propidium iodide after fixation. At least 200 cells were scored by fluorescence microscopy for each determination for apoptotic cells. Columns and bars represent means \pm SEM. Clonogenic assay for X-irradiated MKN45 (panel F), MKN28 (panel G) and Colon26 cells (panel H). ( $\square$ ) X rays only, $(\mathbf{X}) \mathrm{X}$ rays + TAS106. Data are expressed as means \pm SEM for three experiments. 
myl alcohol $=25: 24: 1$ and analyzed by $2 \%$ agarose gel electrophoresis DNA fragments in the gel were detected by staining with ethidium bromide (Sigma).

\section{Analysis of Cell Cycle by Flow Cytometry}

Cells exposed to TAS106 and/or X rays were harvested by treatment with trypsin-EDTA solution. After washing with ice-cold PBS(-), the cells were fixed with ice-cold $70 \%$ ethanol and stored at $4{ }^{\circ} \mathrm{C}$ for $2 \mathrm{~h}$ and RNA was hydrolyzed with $2 \mu \mathrm{g} / \mathrm{ml}$ RNase A (Boehringer Mannheim $\mathrm{GmbH}$, Germany) at $37^{\circ} \mathrm{C}$ for $30 \mathrm{~min}$. Then the cells were stained with propidium iodide (Sigma) for $20 \mathrm{~min}$. The DNA content of cells was analyzed using an EPICS ELITE flow cytometer (Coulter, Miami, FL).

\section{SDS PAGE and Western Blotting}

SDS PAGE and Western blotting were performed as described elsewhere (33). At the indicated times after $\mathrm{X}$ irradiation, cells $\left(2 \times 10^{6}\right)$ were collected by centrifugation at $1,000 \mathrm{rpm}$ for $5 \mathrm{~min}$ at $4^{\circ} \mathrm{C}$. The pellet was washed with PBS(-) and resuspended in $100 \mu 1$ of Laemmli's sample buffer $(62.5 \mathrm{mM}$ Tris- $\mathrm{HCl}, \mathrm{pH} 6.8,10 \%$ glycerol, $2 \%$ SDS, 5\% $\beta$-mercaptoethanol, $0.003 \%$ bromophenol blue) and sonicated twice for $30 \mathrm{~s}$ at ice-cold temperature. Proteins in the solution were separated by SDSPAGE after boiling for $3 \mathrm{~min}$ and transferred onto a nitrocellulose membrane (Advantec Toyo, Tokyo, Japan). The membrane was probed with Cdc25, phospho-Cdc25, Cdc2, phospho-Cdc2, cyclin B, Wee1, Bcl2, BclX $_{\mathrm{L}}$, actin or survivin in TBST buffer $(10 \mathrm{~m} M$ Tris- $\mathrm{HCl}, \mathrm{pH} 7.4,0.1$ $M \mathrm{NaCl}, 0.1 \%$ Tween-20) containing 5\% nonfat milk or 5\% BSA. These were detected by a method using HRP-conjugated anti-rabbit, anti-mouse or anti-goat IgG antibodies with a chemiluminescence detection kit (Boehringer Mannheim GmbH).

\section{Cdc2-Associated H1 Kinase Assay}

Measurements of cyclin-dependent kinase-associated H1 kinase for $\mathrm{Cdc} 2$ were performed by a slight modification of the method described by Fortugno et al. (13). Cells were lysed in lysis buffer (50 $\mathrm{m} M$ Hepes/ $\mathrm{NaOH}, \mathrm{pH} 7.4,150 \mathrm{~m} M \mathrm{NaCl}, 1 \%$ Triton X-100, $1 \mathrm{~m} M$ dithiothreitol, $50 \mathrm{~m} M$ sodium fluoride, $50 \mathrm{~m} M \beta$-glycerophosphate, $1 \mathrm{~m} M$ sodium $o$ vanadate, $1 \mathrm{~m} M$ EDTA, $1 \mathrm{~m} M$ phenyl methylsulfonyl fluoride, $10 \mu \mathrm{g} / \mathrm{ml}$ aprotinin, and $10 \mu \mathrm{g} / \mathrm{ml}$ leupeptin) for $20 \mathrm{~min}$ at $4^{\circ} \mathrm{C}$. The cell lysate was centrifuged at $15,000 \mathrm{~g}$ for $10 \mathrm{~min}$ at $4^{\circ} \mathrm{C}$. The protein content in the supernatant was determined using a Bio-Rad protein assay kit (Hercules, CA). Then $400 \mu \mathrm{g}$ of protein was added to protein A-Sepharose CL-4B (Amersham Pharmacia Biotech, Arlington Heights, IL), preassociated with the anti-Cdc2 antibody, and mixed gently for $2 \mathrm{~h}$ at $4^{\circ} \mathrm{C}$. The immunoprecipitates were washed twice with lysis buffer and twice with wash buffer (50 mM Hepes/ $\mathrm{NaOH}, \mathrm{pH} 7.4,10 \mathrm{~m} M \mathrm{MgCl}_{2}, 1 \mathrm{~m} M$ dithiothreitol) and incubated with $40 \mu \mathrm{l}$ of wash buffer containing $10 \mu \mathrm{g}$ of histone H1 (Boehringer Mannheim GmbH), $10 \mu M$ ATP, $92.5 \mathrm{TBq}[\gamma$ $\left.{ }^{32} \mathrm{P}\right]$ ATP $(185 \mathrm{TBq} / \mathrm{mmol}$, Amersham Pharmacia Biotech) for $10 \mathrm{~min}$ at $30^{\circ} \mathrm{C}$. Each sample was mixed with $20 \mu \mathrm{l}$ of $3 \times$ SDS-sample buffer to stop the reaction, heated for $3 \mathrm{~min}$ at $95^{\circ} \mathrm{C}$ and subjected to SDS-PAGE. The gel was dried and analyzed with a BAS1000 Image Analyzer (Fuji Photo Film, Tokyo, Japan).

\section{RESULTS}

\section{TAS106 Enhances Radiation-Induced Cell Death in} Tumor Cells

Figure 1A shows the effects of $\mathrm{X}$ rays, TAS106 and X rays + TAS106 on apoptosis in MKN45 cells. Either X irradiation or TAS106 alone induced a small number of apoptotic cells at $24 \mathrm{~h}$ and a plateau phase of low-level apoptosis of less than 5\% between $36 \mathrm{~h}$ and $48 \mathrm{~h}$. In con- trast, the number of apoptotic cells increased significantly in MKN45 cells treated with X rays plus TAS106 for $24 \mathrm{~h}$ and produced about $30 \%$ apoptotic cells at $36 \mathrm{~h}$ after treatment. As a biochemical marker of apoptosis, ladder-like DNA fragmentation was also induced by the treatment of cells with X-ray doses of more than 5 Gy plus TAS106 but was not induced when cells were treated with either $\mathrm{X}$ rays or TAS106 alone as shown in Fig. 1B. To examine whether this radiosensitization of apoptosis by TAS106 depended on TP53 status or cell type, in addition to MKN45 cells (TP53 wild-type), we tested the effect of a low dose of TAS106 on apoptosis in MKN28 cells (TP53 mutation) and Colon26 cells (murine rectum adenocarcinoma). In Fig. 1D and $\mathrm{E}$, similar enhancement of radiation-induced apoptosis by TAS106 can be observed in MKN28 cells and Colon26 cells, although the treatment with TAS106 alone at least for $48 \mathrm{~h}$ induced little apoptosis (less than 10\%) in MKN28 and Colon26 cells (data not shown). Furthermore, to evaluate whether TAS106 enhanced radiation-induced reproductive cell death, colony-forming ability was examined. As shown in Fig. 1F, G and $\mathrm{H}$, significant radiosensitization was observed in all cell lines after treatment with TAS106 using a clonogenic assay. These results proved that TAS106 enhanced not only apoptosis but also reproductive cell death in X-irradiated tumor cells regardless of TP53 status and cell type.

\section{TAS106 Enhances Caspase-Dependent Apoptosis and Reduces Accumulation of $G_{2} / M$ Fraction in X-Irradiated Tumor Cells}

To study the relationship between the radiation-induced cell cycle checkpoint and the induction of apoptosis by TAS106, flow cytometric analysis was performed. When cells were exposed to $20 \mathrm{~Gy}$ of $\mathrm{X}$ rays and incubated for $24 \mathrm{~h}$ for MKN45 and $48 \mathrm{~h}$ for MKN28, respectively, the flow cytometric profiles of both cell lines showed marked increases in the $\mathrm{G}_{2} / \mathrm{M}$ fraction (57\% for MKN45 and $78 \%$ for MKN28) but not in the sub- $\mathrm{G}_{1}$ fractions (c in Fig. 2A and $\mathrm{B}$ ), suggesting the occurrence of radiation-induced $\mathrm{G}_{2} /$ $\mathrm{M}$ arrest without apoptosis. As shown in (d) in Fig. 2A and $\mathrm{B}$, the treatment with $\mathrm{X}$ rays + TAS106 resulted in decreases in the $\mathrm{G}_{2} / \mathrm{M}$ fractions ( $28 \%$ for MKN45 and $44 \%$ for MKN28) and increases in the sub- $\mathrm{G}_{1}$ fractions (16\% for MKN45 and 28\% for MKN28). The treatment of cells with TAS106 alone induced accumulation of the $G_{1}$ fraction but not an increase in the sub- $\mathrm{G}_{1}$ fraction (b in Fig. $2 \mathrm{~A}$ and $\mathrm{B}$ ). Observation of the time course of the cell cycle further confirmed that $\mathrm{X}$ irradiation alone induced an increase of the $\mathrm{G}_{2} / \mathrm{M}$ fraction and TAS106 enhanced radiation-induced apoptosis (sub- $\mathrm{G}_{1}$ fraction) and reduced the radiation-induced increase of the $G_{2} / M$ fraction (e-g in Fig. 2A and B). A similar reduction of the $\mathrm{G}_{2} / \mathrm{M}$ fraction and enhancement of the radiation-induced apoptosis by treatment with TAS106 were also observed in irradiated Colon26 cells (data not shown). 


\section{A MKN45}

(a) control
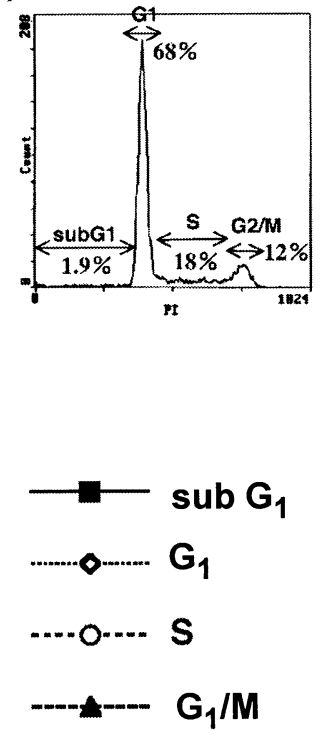

B MKN28

(a) control

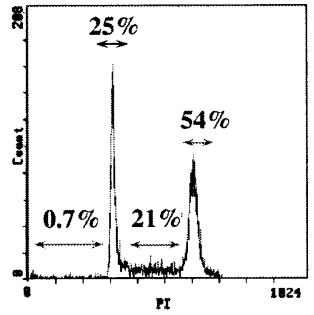

(b) TAS106 (24h)

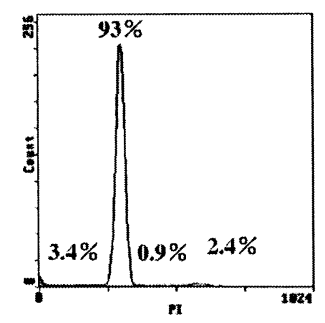

(e) TAS106

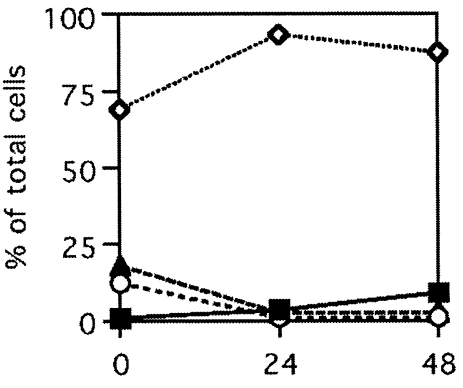

time (h) (c) X rays $(24 \mathrm{~h})$

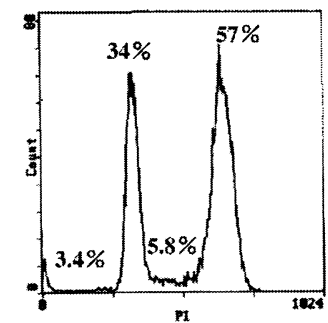

(f) $X$ rays

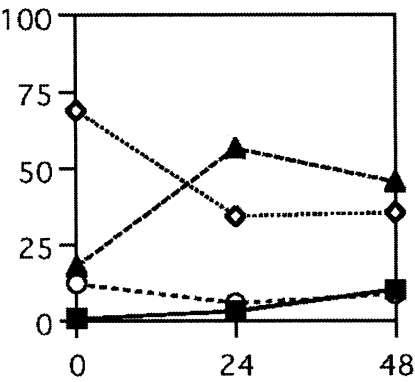

time (h) (d) X rays + TAS106 $(24 \mathrm{~h})$

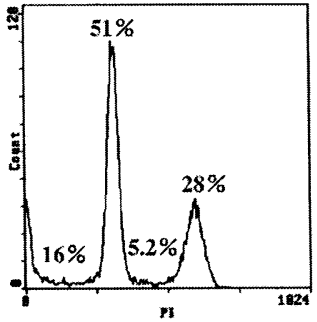

(g) $X$ rays + TAS106

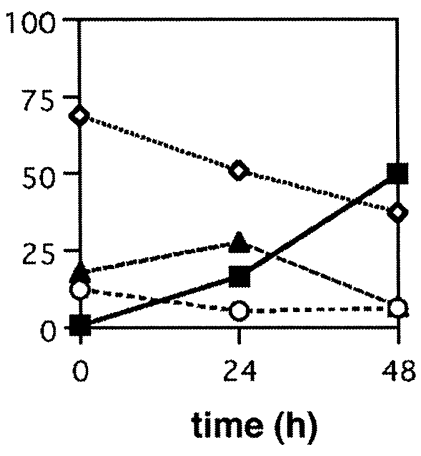

(d) $X$ rays + TAS106 $(48 \mathrm{~h})$

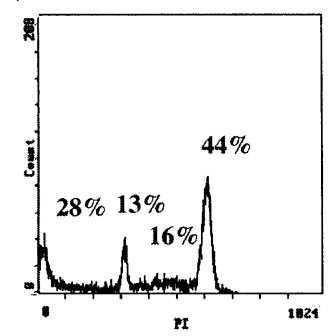

(g) X rays + TAS106

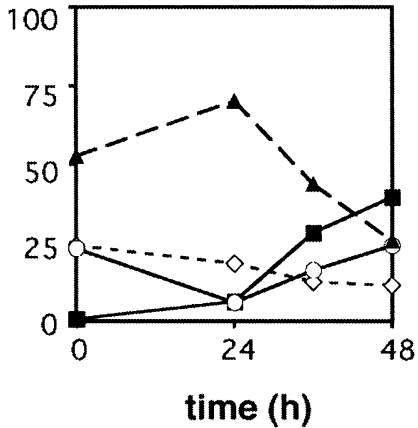

FIG. 2. Cell cycle analysis of MKN45 and MKN28 cells treated with TAS106 and/or X rays. Panel A: MKN45 cells treated with TAS106, X rays and X rays + TAS106 were incubated at $37^{\circ} \mathrm{C}$ for 24 and $48 \mathrm{~h}$. Panel B: MKN28 cells treated with TAS106, 20 Gy of X rays or X rays + TAS106 were incubated at $37^{\circ} \mathrm{C}$ for 24 and $48 \mathrm{~h}$. After incubation, cells were collected, fixed and stained with propidium iodide. The DNA content was measured by flow cytometry. Ten thousand events were captured for each treatment. Typical histograms of MKN45 (panel A) and MKN28 (panel B) cells from untreated control, TAS106, X rays and X rays + TAS106 are shown in (a) to (d), respectively. Time courses of cell cycle of cells exposed to TAS106, $X$ rays or X rays + TAS106 are shown in (e), (f) and (g), respectively. ( $\square$ ) sub- $G_{1}$ fraction, ( $\left.\diamond\right) G_{1}$ fraction, $(\bigcirc) S$ fraction, $(\boldsymbol{\Delta}) G_{2} / M$ fraction 

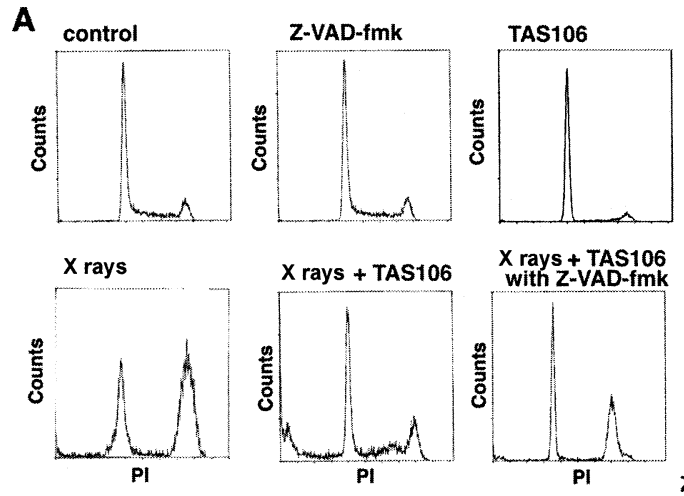

FIG. 3. Effects of a caspase inhibitor, Z-VAD-fmk, on cell cycle of MKN45 cells exposed to X rays + TAS106. Panel A: Cells were exposed to Z-VAD-fmk, TAS106, X rays, X rays + TAS106 or X rays + TAS106 with Z-VAD-fmk, and incubated at $37^{\circ} \mathrm{C}$ for $24 \mathrm{~h}$. Cells were collected and stained with propidium iodide after fixation. The DNA content was measured by flow cytometry. Data concerning the cell cycle obtained from three independent experiments are summarized in panel B. Columns and bars represent means \pm SEM.

We next examined the effect of a caspase inhibitor, ZVAD-fmk, on apoptosis in MKN45 cells treated with $\mathrm{X}$ rays and/or TAS106. Figure 3 shows that the $G_{2} / M$ fraction was markedly increased by treatment with $\mathrm{X}$ rays but not by that with Z-VAD-fmk or TAS106 in comparison with the control. Treatment with X rays + TAS106 significantly reduced the $\mathrm{G}_{2} / \mathrm{M}$ fraction and increased the sub- $\mathrm{G}_{1}$ fraction in comparison with the cells treated with $\mathrm{X}$ rays alone. The presence of Z-VAD-fmk significantly inhibited the formation of the sub- $G_{1}$ fraction and increased the $G_{2} / M$ fraction in cells exposed to $\mathrm{X}$ rays + TAS106. Furthermore, using Ac-DEVD-MCA, a fluorescent caspase 3 substrate, we observed caspase 3 activation in the cell lysate at $36 \mathrm{~h}$ after $\mathrm{X}$ rays + TAS106 but not after X rays or TAS106 alone (data not shown). These results mean that caspase activation induced by X rays + TAS106 is involved in apoptosis.

\section{TAS106 Attenuates Expression of Phospho-Cdc2, Cyclin B1 and Wee1 in MKN45 Cells}

In cells exposed to $\mathrm{X}$ rays, the phosphorylation of $\mathrm{Cdc} 2$ and the accumulation of cyclin B1 are known to be important signals for the $\mathrm{G}_{2} / \mathrm{M}$ checkpoint after DNA damage. In MKN45 cells $X$ irradiation induced the accumulation of phospho-Cdc2 and cyclin B1 (left panel in Fig. 4A) and a slight increase in the histone $\mathrm{H} 1$ kinase activity of $\mathrm{Cdc} 2$ (second lane in Fig. 4B). Treatment with TAS106 not only suppressed basal expression of phospho-Cdc2, cyclin B1 and Wee1 (middle panel in Fig. 4A) but also abrogated Xray-induced increases of expression of phospho-Cdc2 and cyclin B1 (right panel in Fig. 4A). The histone H1 kinase activity of $\mathrm{Cdc} 2$ was also remarkably inhibited by treatment with TAS106 in comparison with that after $\mathrm{X}$ rays alone (third and fourth lanes in Fig. 4B). These results indicate that TAS106 inhibits expression of cell cycle control protein during the radiation-induced $\mathrm{G}_{2} / \mathrm{M}$ checkpoint.

\section{Down-regulation of Expression of Survivin in MKN45, MKN28 and Colon26 Cells Treated with TAS106}

To analyze the molecules responsible for X-ray-induced caspase-dependent apoptosis in the presence of TAS106, the expression of anti-apoptosis proteins was examined in MKN45, MKN28 and Colon26 cells treated with TAS106. The results of Western blotting for survivin, Bcl2 and $\mathrm{BclX}_{\mathrm{L}}$ are shown in Fig. 5. In all cell lines, the expression of survivin was markedly suppressed by the treatment with TAS106 alone or X rays + TAS106. Large amounts of $\mathrm{Bcl} 2$ and $\mathrm{BclX}_{\mathrm{L}}$ protein existed in MKN45 cells treated with TAS106 alone or X rays + TAS106. However, for MKN28 and Colon26 cells, the expression of survivin and Bcl2 was suppressed markedly in cells treated with TAS106 alone or X rays + TAS106, but expression of $\mathrm{BclX}_{\mathrm{L}}$ was not changed by these treatments.

\section{Transient Overexpression of Wild-Type Survivin Inhibits Apoptosis Induced by X Rays + TAS106}

To clarify whether the down-regulation of survivin during the $\mathrm{X}$-ray-induced $\mathrm{G}_{2} / \mathrm{M}$ checkpoint was responsible for the induction of caspase-dependent apoptosis, we examined the effect of overexpression of wild-type survivin on radiation-induced cell death in the presence and absence of TAS106. The amount of survivin in cells transfected with pCIneo survivin was increased considerably in comparison with that of untransfected or mock-transfected cells as confirmed by Western blotting (Fig. 6A). Figure 6B shows the X-ray + TAS106-induced apoptosis in MKN45 cells overexpressing survivin. The cells with morphological changes indicative of apoptosis were scored GFP-positive cells, which contained pCIneo survivin. The induction of apoptosis by $\mathrm{X}$ rays + TAS106 was significantly inhibited by transfection of pCIneo survivin. These results strongly suggested that down-regulation of survivin by TAS106 played an important role in the radiosensitization of apoptosis in MKN45 cells. Next we examined effects of overexpression of survivin on abrogation of the $\mathrm{G}_{2} / \mathrm{M}$ checkpoint by X-ray + TAS106 treatment. The sub- $\mathrm{G}_{1}$ fraction was observed to be $24 \%$ in MKN45 cells at $36 \mathrm{~h}$ after transfection with pCIneo or pCIneo survivin [Fig. 6C (1) and C (2)]. When cells transfected with pCIneo were irradiated in the presence of TAS 106 and incubated for $36 \mathrm{~h}$, the sub- $\mathrm{G}_{1}$ fraction 


\begin{abstract}
A
X ray

TAS106

X ray + TAS106

no treatment $0 \quad 12 \quad 24 \quad 36 \mathrm{~h}$

$\begin{array}{llll}0 & 12 & 24 & 36 \mathrm{~h}\end{array}$

$\begin{array}{llll}0 & 12 & 24 & 36 \mathrm{~h}\end{array}$

Phospho-
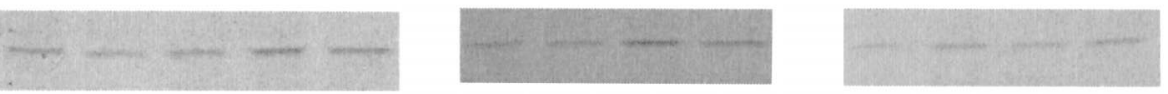

Phospho-
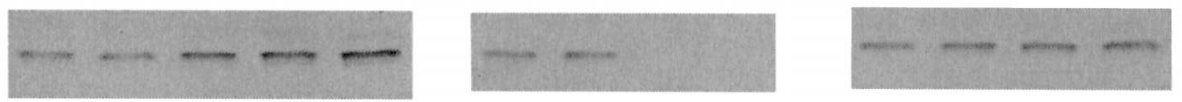

Cdc25C
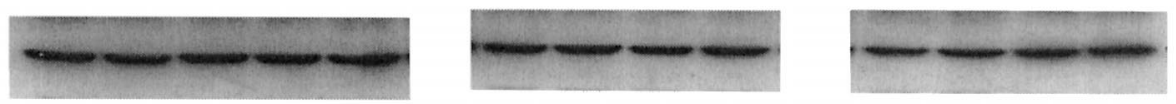

Cdc2
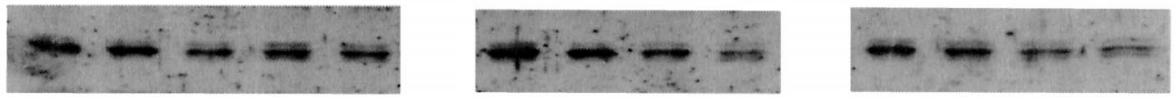

cyclin B1
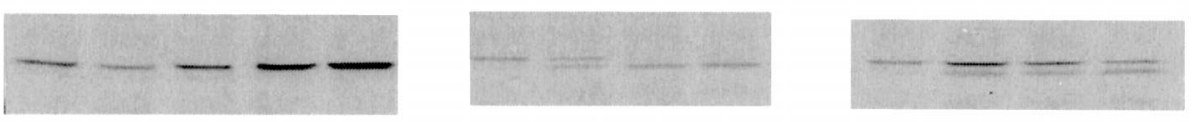

Wee1
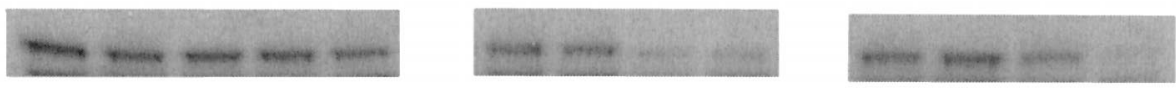

actin
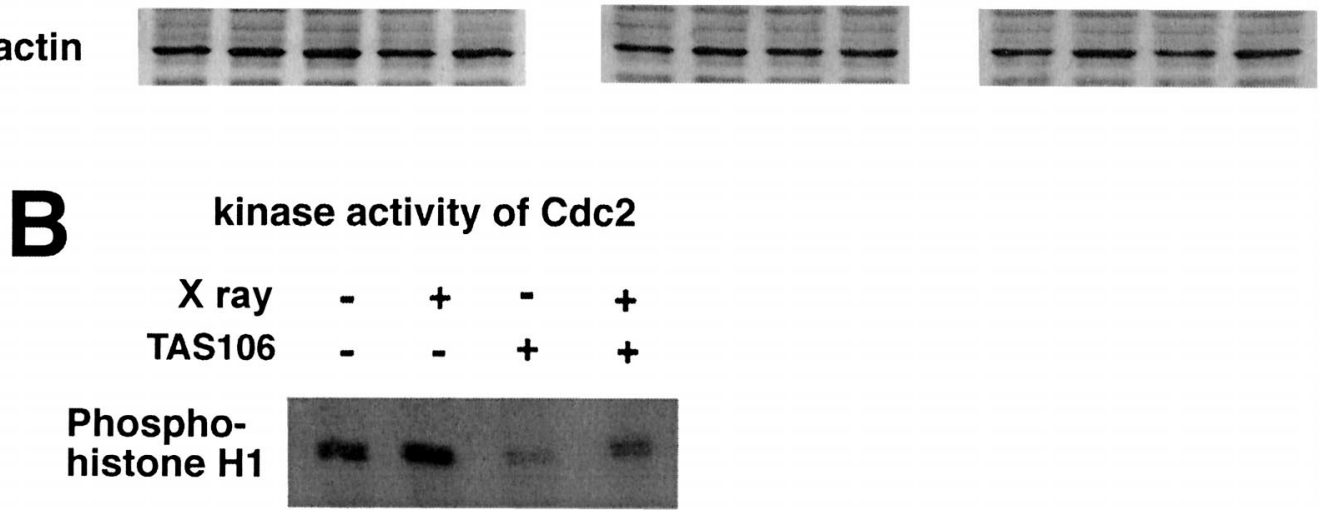

FIG. 4. TAS106 suppresses the expression of proteins related to the $\mathrm{G}_{2} / \mathrm{M}$ checkpoint. MKN45 cells treated with $\mathrm{X}$ rays, TAS106 and $\mathrm{X}$ rays + TAS106 were incubated at $37^{\circ} \mathrm{C}$ for several hours. Panel A: Western blots of protein lysate $(10 \mu \mathrm{g} / \mathrm{lane})$ were prepared at the indicated times. Blots were probed with antibodies to phospho-Cdc25C, phospho-Cdc2, Cdc25, Cdc2, cyclin B1, Wee1 and actin, respectively. Panel B: Cdc2 was immunoprecipitated from MKN45 cells exposed to TAS106, X rays and X rays + TAS106 for $24 \mathrm{~h}$. The reaction mixture of histone H1 and immunoprecipitated $\mathrm{Cdc} 2$ was incubated in the presence of $\left[\gamma^{-32} \mathrm{P}\right] \mathrm{ATP}$ for $10 \mathrm{~min}$ at $30^{\circ} \mathrm{C}$ as described in the Materials and Methods. Phosphorylated histone H1 was subjected to 10\% SDS-PAGE and visualized by autoradiography.
\end{abstract}

was $62 \%$ [Fig. 6C (3)]. Transfection with pCIneo survivin decreased X-ray + TAS106-induced apoptosis in the sub$\mathrm{G}_{1}$ fraction (42\%) [Fig. 6C (4)]. Furthermore, the treatment with $\mathrm{X}$ rays + TAS106 induced reduction of the $\mathrm{G}_{2} / \mathrm{M}$ fraction in the cells transfected with pCIneo, whereas transfection of pCIneo survivin significantly inhibited this X-ray + TAS106-induced decrease of the $\mathrm{G}_{2} / \mathrm{M}$ fraction. Taken together, our present findings indicate that the loss of function of surviving caused by TAS106 is partly responsible for radiation-induced apoptosis during mitosis.

\section{DISCUSSION}

In radiosensitization of tumor cells and tissues, pharmacological agents with the ability to abrogate the $\mathrm{G}_{2} / \mathrm{M}$ checkpoint have been of interest for many years. UCN-01 (2-6), an indolocarbazole (SB-218078) (7) and caffeine (810) have been shown to be able to abrogate the $G_{2} / M$ checkpoint and enhance radiation-induced cytotoxicity. Recently, the preferential potentiation of radiation toxicity by UCN-01 was reported to cause apoptosis (6). The inhibition 
MKN45

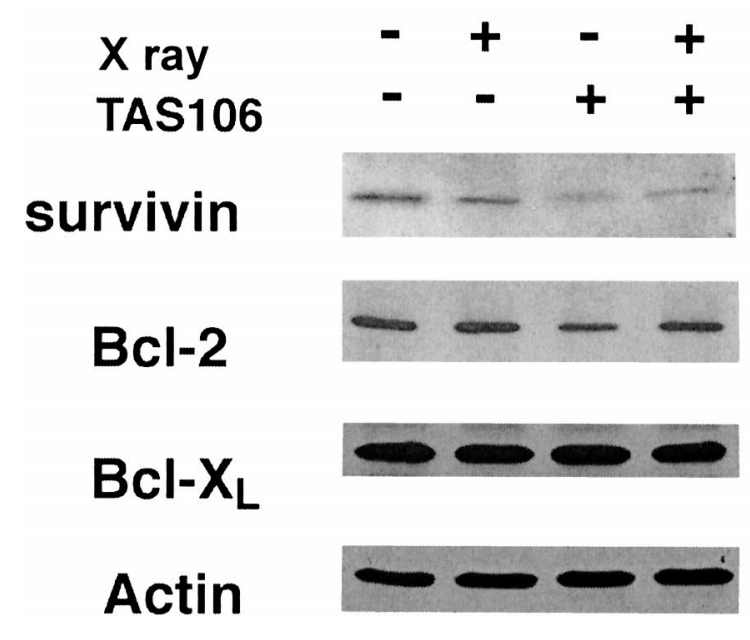

MKN28
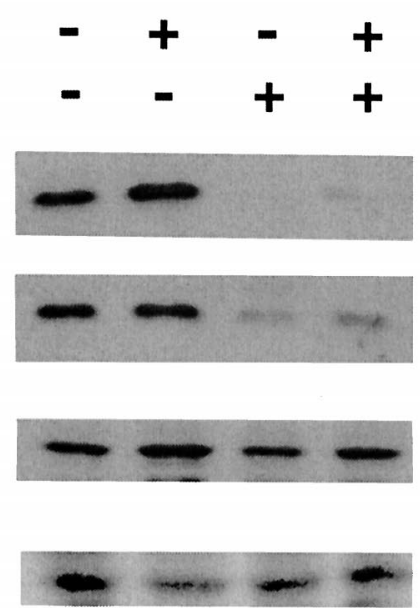

Colon26
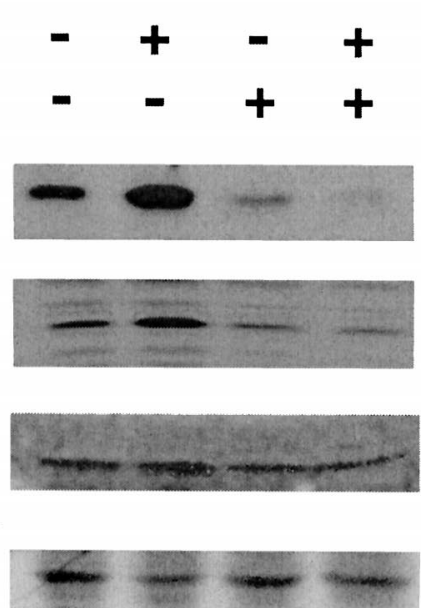

FIG. 5. Effects of TAS106 on the protein expression of survivin, Bcl2, BclX $\mathrm{L}_{\mathrm{L}}$ and actin in MKN45, MKN28 and Colon26 cells exposed to X rays. Incubation in the presence of TAS106 was performed for $48 \mathrm{~h}$ for MKN28 cells, $24 \mathrm{~h}$ for MKN45 cells, and $24 \mathrm{~h}$ for Colon26 cells. Protein lysates were prepared from MKN45 (panel A), MKN28 (panel B) and Colon26 (panel C) cells exposed to TAS106, X rays or X rays + TAS106. Proteins of cell lysate $(10 \mu \mathrm{g} / \mathrm{lane})$ were separated using 15\% SDS-PAGE and transferred to nitrocellulose membranes. Blot membranes were probed with antibodies to survivin, $\mathrm{Bcl} 2, \mathrm{BclX} \mathrm{L}_{\mathrm{L}}$ and actin as described in the Methods and Materials section, respectively.

of Chk1 by UCN-01 and SB-218078 and the inhibition of ATM and ATR by caffeine were proposed as mechanisms of the abrogation of the $\mathrm{G}_{2} / \mathrm{M}$ checkpoint. Moreover, the down-regulation of $\mathrm{Cdc} 2$ and cyclin $\mathrm{B} 1$ by overexpression of double-stranded RNA-activated, serine/threonine protein kinase, PKR, was shown to induce apoptosis in $\mathrm{CHO}$ cells (36). In the present experiments, we found that a low concentration of a novel antitumor agent, TAS106, enhanced radiation-induced apoptosis and reproductive cell death, as shown in Fig. 1. Moreover, it seemed that this radiosensitization by TAS106 occurred in a TP53-independent manner because of observations obtained from the TP53-mutated cell line MKN28 (Fig. 1D and G and 2B). As shown in Fig. 3, an increase of the $\mathrm{G}_{2} / \mathrm{M}$ fraction, but not the sub$\mathrm{G}_{1}$ fraction, was observed in MKN45 cells exposed to $\mathrm{X}$ rays only, and the treatment with TAS106 decreased this radiation-induced increase in the $\mathrm{G}_{2} / \mathrm{M}$ fraction and enhanced the sub- $\mathrm{G}_{1}$ fraction in MKN45 cells treated with $\mathrm{X}$ rays. As for expression of cell cycle proteins, TAS106 inhibited the Cdc2 kinase activity and reduced the protein expression of phospho-Cdc2, cyclin B1 and Wee1 in Xirradiated MKN45 cells (Fig. 5). These results may indicate an association between enhancement of radiation-induced cell death and abrogation of the $\mathrm{G}_{2} / \mathrm{M}$ checkpoint by TAS106. However, further experiments will be necessary to clarify whether enhancement of radiation-induced cell death by TAS106 is caused by down-regulation of cell cycle proteins associated with the $\mathrm{G}_{2} / \mathrm{M}$ progression and checkpoint.

Next, to search for the key molecule in X-ray + TAS106-induced apoptosis, we examined the effects of TAS106 on expression of anti-apoptosis proteins. Western blotting showed that survivin was greatly suppressed by TAS106 in MKN45, MKN28 and Colon26 cells, and Bcl2 was moderately suppressed by TAS106 in MKN28 and Colon 26 cells but not MKN45 cells. The expression of $\mathrm{BclX}_{\mathrm{L}}$ was hardly influenced by TAS106 in these three cell lines. The mechanism of the differential effect of TAS106 on the expression of anti-apoptosis proteins is unclear, but might be explained by the difference in the lifetime of mRNA in each protein, because TAS106 has been reported to be a global inhibitor for RNA synthesis in tumor cells (28). Raghavan et al. measured mRNA decay of 6000 expressed transcripts in $\mathrm{T}$ lymphocytes treated with actinomycin $\mathrm{D}$ by using microarray technology, and found half-lives from a few minutes $\left(T_{1 / 2}=10 \mathrm{~min}\right)$ to several hours $\left(T_{1 / 2}>6 \mathrm{~h}\right)$ and that numerous transcripts exhibited stimulus-dependent changes in their half-lives (37). In fact, we observed that the treatment with TAS106 for $24 \mathrm{~h}$ suppressed mRNA expression of survivin and $\mathrm{Bcl} 2$ but not that of $\mathrm{BclX}_{\mathrm{L}}$ and GAPDH in MKN45 cells (data not shown).

The expression of survivin was reported to be observable in embryonic and fetal organs but not in most terminally differentiated normal cells. By contrast, dramatic overexpression of survivin compared with normal tissues was demonstrated in tumors of the lung, breast, colon, esophagus, pancreas, bladder, stomach, uterus and ovary, as well as in melanoma, large cell non-Hodgkin's lymphoma, leukemia and neuroblastoma [see review by Altieli (12)], suggesting that alteration of survivin gene regulation occurs commonly during tumorigenesis. Overexpression of survivin was observed in 60 tumor cell lines on the NCI anticancer drug screening panel, demonstrating that transient overexpression of survivin inhibited etoposide-, Fas- and 


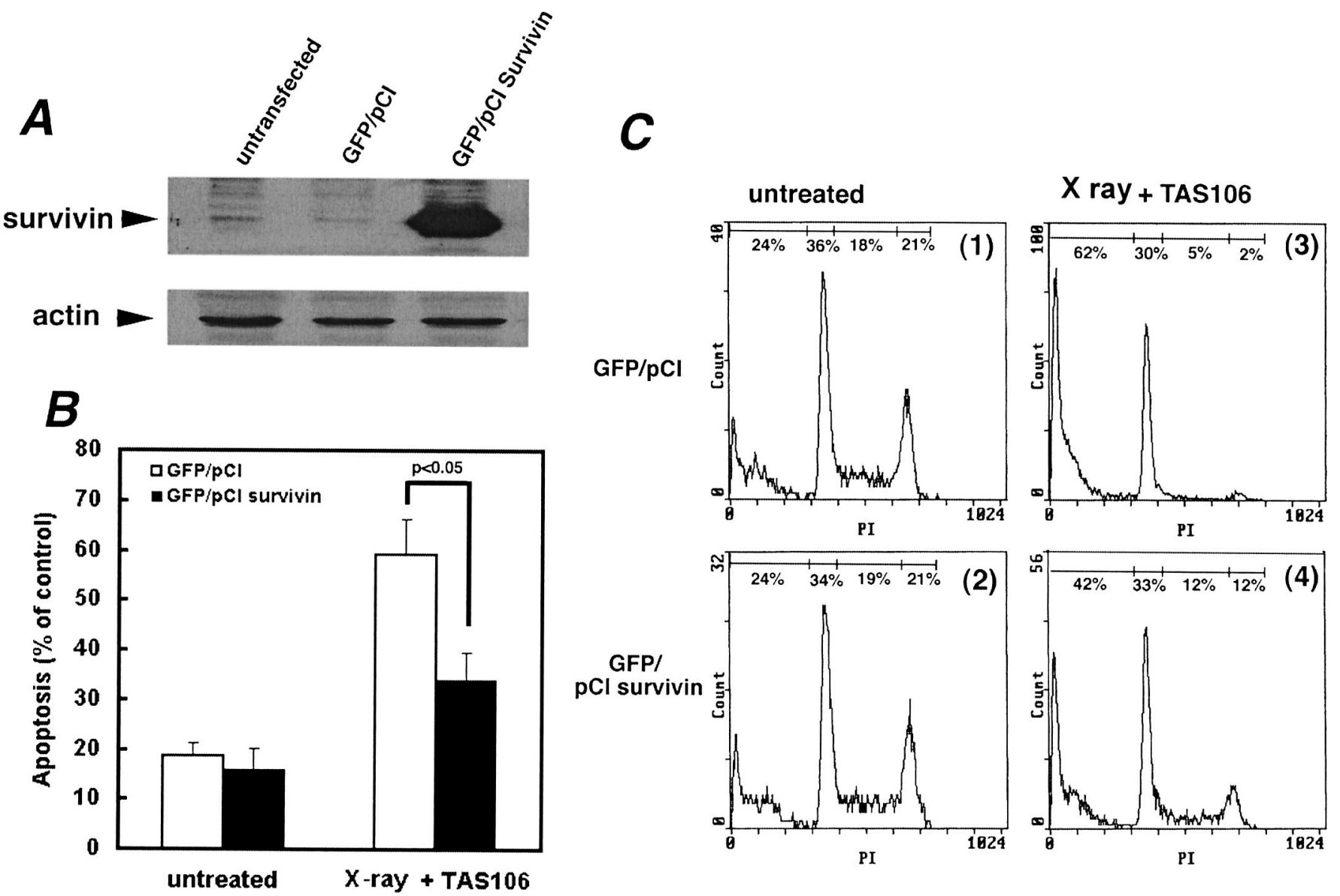

FIG. 6. Expression of wild-type survivin leads to inhibition of apoptosis induced in MKN45 cells treated with X rays + TAS106. MKN45 cells were transfected with pCIneo or pCIneo survivin, together with pQBI-GFP. Panel A: Western blotting of survivin expression and actin at $36 \mathrm{~h}$ after transfection. The MKN45 cells transfected with pCIneo or pCIneo survivin were incubated for $36 \mathrm{~h}$ after treatment with X rays + TAS106 and then fixed with $70 \%$ methanol. The cells were stained by propidium iodide. Panel A: The apoptotic cells among GFP-positive 500 cells were scored by a method similar to that described in the legend to Fig. 1A. Data are expressed as means \pm SEM for three experiments. $* P<0.05$ significant difference between apoptosis in the cells transfected with pCIneo and those with pCIneo survivin. Panel B: For analysis of the cell cycle, the GFP-positive cells were gated by flow cytometry and the cell cycle of the GFP-positive cells was examined.

Bax-induced caspase-dependent apoptosis (16). Yu et al. have demonstrated that five gastric cell lines, including MKN45 cells, and 34 of 50 human gastric cancer tissues (68\%), highly express survivin mRNA (38). Several reports have demonstrated that radioresistance and chemoresistance in tumors are due to the overexpression of survivin (1315). In this experiment, we found that the treatment with TAS106 efficiently induced down-regulation of survivin expression regardless of the type of tumor cell. This finding may be noteworthy for the application of TAS 106 to tumor therapy.

O'Connor et al. showed that survivin overexpressed in cancer was physically associated with $\mathrm{Cdc} 2$ in the mitotic apparatus and phosphorylated on Thr34 by Cdc2-cyclin B1 in vitro and in vivo (17). This phosphorylation on Thr34 of survivin was required for the inhibition of both caspasedependent and caspase-independent apoptosis of cells traversing mitosis (17-20). These data indicate that survivin serves as a mitotic substrate of Cdc2-cyclin B1 and that physical association of survivin with Cdc2-cyclin B1 is necessary to preserve cell viability during cell division. In this study, it was shown that Cdc2 kinase activity was upregulated by X-irradiated MKN45 cells and that TAS106 greatly suppressed this activity, as shown in Fig. 4B, suggesting that phosphorylated survivin, as an active form to inhibit the caspase cascade, might be reduced by TAS106induced suppression of kinase activity of Cdc2. Furthermore, the demonstration that overexpression of survivin reduces X-ray + TAS106-induced apoptosis implies that loss of function of survivin is an important factor for radiosensitization in the induction of apoptosis in the $\mathrm{G}_{2} / \mathrm{M}$ phase by TAS106.

RNA synthesis and protein synthesis inhibitors such as actinomycin D (Act D) (39) and cycloheximide (CHX) (40) are well known as strong inducers of apoptosis, and treatment of cells with Act D or CHX is reported to suppress expression of survivin $(24,39)$. We observed that Act D down-regulated survivin expression and radiosensitized MKN45 cells in a fashion similar to that of TAS106 (data not shown). However, general RNA or protein synthesis 
inhibitors cannot be used for clinical application in tumor treatment because of their nonspecificity with regard to cell type. Matsuda and colleagues have demonstrated that TAS106 is phosphorylated by intracellular uridine/cytidine kinase $2(41,42)$, which has high activity in tumor cells relative to normal cells (43). This phosphorylated TAS106 (ECTP) gained high cytotoxicity for tumor cells through its inhibition of RNA synthesis. Thus TAS106 appears to have an advantage in specificity for tumor therapy. In this experiment, treatment with low doses of TAS106 induced abrogation of the $\mathrm{X}$-ray-induced $\mathrm{G}_{2} / \mathrm{M}$ checkpoint and the down-regulation of the anti-apoptosis molecule survivin and then enhanced not only apoptosis but also reproductive cell death. It is well known that apoptotic cells, relative to necrotic cells, are easily eliminated from normal tissue by phagocytosis without severe inflammatory responses. Therefore, the manipulation of the survivin/caspase pathway by using the combination of a low concentration of TAS106 and radiation may facilitate not only cell death but also elimination of cancer cells in vivo.

\section{ACKNOWLEDGMENTS}

This work was supported in part by Grants-in-Aid for Basic Scientific Research from the Ministry of Education, Culture, Sports, Science and Technology of Japan [No. 15380199 (OI), No. 14636111 (OI) No. 15780200 (TA), No. 15025202 (MK) and No. 16023206 (MK)], and by Grants-in-Aid to Cooperative Research in the Rakuno Gakuen University. This work was also supported by Research Fellowships of the Japan Society for the Promotion of Science (JSPS) for Young Scientists to TY.

Received: December 19, 2003; accepted: July 19, 2004

\section{REFERENCES}

1. K. K. Khanna, M. F. Lavin, S. P. Jackson and T. D. Mulhern, ATM, a central controller of cellular responses to DNA damage. Cell Death Differ. 8, 1052-1065 (2001).

2. K. Sugiyama, M. Shimizu, T. Akiyama, T. Tamaoki, K. Yamaguchi, R. Takahashi, A. Eastman and S. Akinaga, UCN-01 selectively enhances mitomycin $\mathrm{C}$ cytotoxicity in p53 defective cells which is mediated through $\mathrm{S}$ and/or $\mathrm{G}_{2}$ checkpoint abrogation. Int. J. Cancer $\mathbf{8 5}$, 703-709 (2000).

3. L. Yu, L. Orlandi, P. Wang, M. S. Orr, A. M. Senderowicz, E. A. Sausville, R. Silvestrini, N. Watanabe, H. Piwnica-Worms and P. M. O'Connor, UCN-01 abrogates $\mathrm{G}_{2}$ arrest through a Cdc2-dependent pathway that is associated with inactivation of the WeelHu kinase and activation of the Cdc25C phosphatase. J. Biol. Chem. 273, 33455-33464 (1998).

4. Q. Yu, J. La Rose, H. Zhang, H. Takemura, K. W. Kohn and Y. Pommier, UCN-01 inhibits p53 up-regulation and abrogates gammaradiation-induced $\mathrm{G}_{2}-\mathrm{M}$ checkpoint independently of $\mathrm{p} 53$ by targeting both of the checkpoint kinases, Chk2 and Chk1. Cancer Res. 62, 5743-5748 (2002).

5. L. C. Playle, D. J. Hicks, D. Qualtrough and C. Paraskeva, Abrogation of the radiation-induced $\mathrm{G}_{2}$ checkpoint by the staurosporine derivative $\mathrm{UCN}-01$ is associated with radiosensitisation in a subset of colorectal tumour cell lines. Br. J. Cancer 87, 352-358 (2002).

6. H. H. Xiao, Y. Makeyev, J. Butler, B. Vikram and W. A. Franklin, 7-Hydroxystaurosporine (UCN-01) preferentially sensitizes cells with a disrupted TP53 to gamma radiation in lung cancer cell lines. Radiat. Res. 158, 84-93 (2002).

7. J. R. Jackson, A. Gilmartin, C. Imburgia, L. D. Winkler, L. A. Mar- shall and A. Roshak, An indolocarbazole inhibitor of human checkpoint kinase (Chk1) abrogates cell cycle arrest caused by DNA damage. Cancer Res. 60, 566-572 (2000).

8. T. S. Bracey, A. C. Williams and C. Paraskeva, Inhibition of radiation-induced $\mathrm{G}_{2}$ delay potentiates cell death by apoptosis and/or the induction of giant cells in colorectal tumor cells with disrupted p53 function. Clin. Cancer Res. 3, 1371-1381 (1997).

9. K. Higuchi, N. Mitsuhashi, J. Saitoh, K. Maebayashi, H. Sakurai, T. Akimoto and $\mathrm{H}$. Niibe, Caffeine enhanced radiosensitivity of rat tumor cells with a mutant-type p53 by inducing apoptosis in a p53independent manner. Cancer Lett. 152, 157-162 (2000).

10. B-B. S. Zhou, P. Chaturvedi, K. Spring, S. P. Scott, R. A. Johanson, R. Mishra, M. R. Mattern, J. D. Winkler and K. K. Khanna, Caffeine abolishes the mammalian $\mathrm{G}_{2} / \mathrm{M}$ DNA damage checkpoint by inhibiting ataxia-telangiectasia-mutated kinase activity. J. Biol. Chem. 275, 10342-10348 (2000).

11. Q. Yu, J. H. Rose, H. Zhang and Y. Pommier, Antisense inhibition of Chk2/hCds1 expression attenuates DNA damage-induced S and $\mathrm{G}_{2}$ checkpoints and enhances apoptotic activity in HEK-293 cells. FEBS Lett. 505, 7-12 (2001).

12. D. C. Altieri, The molecular basis and potential role of survivin in cancer diagnosis and therapy. Trends Mol. Med. 7, 542-547 (2001).

13. P. Fortugno, N. R. Wall, A. Giodini, D. S. O'Connor, J. Plescia, K. M. Padgett, S. Tognin, P. C. Marchisio and D. C. Altieri, Survivin exists in immunochemically distinct subcellular pools and is involved in spindle microtubule function. J. Cell Sci. 115, 575-585 (2002).

14. R. A. Olie, A. P. Simoes-Wust, B. Baumann, S. H. Leech and D. Fabbro, A novel antisense oligonucleotide targeting survivin expression induces apoptosis and sensitizes lung cancer cells to chemotherapy. Cancer Res. 60, 2805-2809 (2000).

15. K. Asanuma, D. Kobayashi, D. Furuya, N. Tsuji, A. Yagihashi and N. Watanabe, A role for survivin in radioresistance of pancreatic cancer cells. Jpn. J. Cancer Res. 93, 1057-1062 (2002).

16. I. Tamm, Y. Wang, E. Sausville, D. A. Scudiero, N. Vigna, T. O1tersdorf and J. C. Reed, IAP-family protein survivin inhibits caspase activity and apoptosis induced by Fas (CD95), Bax, caspases, and anticancer drugs. Cancer Res. 58, 5315-5320 (1998).

17. D. S. O'Connor, D. Grossman, J. Plescia, F. Li, H. Zhang, A. Villa, S. Tognin, P. C. Marchisio and D. C. Altieri, Regulation of apoptosis at cell division by p34cdc2 phosphorylation of survivin. Proc. Natl. Acad. Sci. USA 97, 13103-13107 (2000).

18. D. Grossman, P. J. Kim, J. S. Schechner and D. C. Altieri, Inhibition of melanoma tumor growth in vivo by survivin targeting. Proc. Natl. Acad. Sci. USA 98, 635-640 (2001).

19. M. Mesri, N. R. Wall, J. Li, R. W. Kim and D. C. Altieri, Cancer gene therapy using a survivin mutant adenovirus. J. Clin. Invest. 108, 981-990 (2001).

20. M. Pennati, G. Colella, M. Folini, L. Citti, M. G. Daidone and N. Zaffaroni, Ribozyme-mediated attenuation of survivin expression sensitizes human melanoma cells to cisplatin-induced apoptosis. $J$. Clin. Invest. 109, 285-286 (2002).

21. E. M. Conway, S. Pollefeyt, J. Cornelissen, I. DeBaere, M. SteinerMosonyi, K. Ong, M. Baens, D. Collen and A. C. Schuh, Three differentially expressed survivin cDNA variants encode proteins with distinct antiapoptotic functions. Blood 95, 1435-1442 (2000).

22. S. Shin, B. J. Sung, Y. S. Cho, H. J. Kim, N. C. Ha, J. I. Hwang, C. W. Chung, Y. K. Jung and B. H. Oh, An anti-apoptotic protein human survivin is a direct inhibitor of caspase-3 and -7. Biochemistry 40, 1117-1123 (2001).

23. S. L. Shankar, S. Mani, K. N. O'Guin, E. R. Kandimalla, S. Agrawal and B. Shafit-Zagardo, Survivin inhibition induces human neural tumor cell death through caspase-independent and -dependent pathways. J. Neurochem. 79, 426-436 (2001).

24. J. Zhao, T. Tenev, L. M. Martins, J. Downward and N. R. Lemoine, The ubiquitin-proteasome pathway regulates survivin degradation in a cell cycle-dependent manner. J. Cell Sci. 113, 4363-4371 (2000).

25. A. Vantieghem, Y. Xu, Z. Assefa, J. Piette, J. R. Vandenheede, W. Merlevede, P. A. De Witte and P. Agostinis, Phosphorylation of Bcl2 in $\mathrm{G}_{2} / \mathrm{M}$ phase-arrested cells following photodynamic therapy with 
hypericin involves a CDK1-mediated signal and delays the onset of apoptosis. J. Biol. Chem. 277, 37718-37731 (2002).

26. H. Hattori, M. Tanaka, M. Fukushima, T. Sasaki and A. Matsuda, Nucleosides and nucleotides. 158. 1-(3-C-ethynyl-beta-D-ribo-pentofuranosyl)-cytosine, 1-(3-C-ethynyl-beta-D-ribo-pentofuranosyl)uracil, and their nucleobase analogues as new potential multifunctional antitumor nucleosides with a broad spectrum of activity. J. Med. Chem. 39, 5005-5011 (1996).

27. S. Takatori, H. Kanda, K. Takenaka, Y. Wataya, A. Matsuda, M. Fukushima, Y. Shimamoto, M. Tanaka and T. Sasaki, Antitumor mechanisms and metabolism of the novel antitumor nucleoside analogues, 1-(3-C-ethynyl-beta-D-ribo-pentofuranosyl)cytosine and 1(3-C-ethynyl-beta-D-ribo-pentofuranosyl)uracil. Cancer Chemother. Pharmacol. 44, 97-104 (1999).

28. A. Matsuda, M. Fukushima, Y. Wataya and T. Sasaki, A new antitumor nucleoside, 1-(3-C-ethynyl-beta-D-ribo-pentofuranosyl)cytosine (ECyd), is a potent inhibitor of RNA synthesis. Nucleosides Nucleotides 18, 811-814 (1999).

29. Y. Shimamoto, H. Kazuno, Y. Murakami, A. Azuma, K. Koizumi, A. Matsuda, T. Sasaki and M. Fukushima, Antitumor activity and pharmacokinetics of TAS-106, 1-(3-C-ethynyl-beta-D-ribo-pentofuranosyl)cytosine. Jpn. J. Cancer Res. 93, 445-452 (2002).

30. A. Azuma, A. Matsuda, T. Sasaki and M. Fukushima, 1-(3-C-ethynylbeta-D-ribo-pentofuranosyl)cytosine (ECyd, TAS-106)1: Antitumor effect and mechanism of action. Nucleosides Nucleotides Nucleic Acids 20, 609-619 (2001).

31. Y. Shimamoto, A. Fujioka, H. Kazuno, Y. Murakami, H. Ohshimo, T. Kato, A. Matsuda, T. Sasaki and M. Fukushima, Antitumor activity and pharmacokinetics of TAS-106, 1-(3-C-ethynyl-beta-D-ribo-pentofuranosyl)cytosine. Jpn. J. Cancer Res. 92, 343-351 (2001).

32. O. Inanami, K. Takahashi and M. Kuwabara, Attenuation of caspase3-dependent apoptosis by Trolox post-treatment of X-irradiated MOLT-4 cells. Int. J. Radiat. Biol. 75, 155-163 (1999).

33. K. Takahashi, O. Inanami, M. Hayashi and M. Kuwabara, Protein synthesis-dependent apoptotic signalling pathway in X-irradiated MOLT-4 human leukemia cell line. Int. J. Radiat. Biol. 78, 115-124 (2002).

34. N. Ramakrishnan and G. N. Catravas, N-(2-mercaptoethyl)-1,3-propanediamine (WR-1065) protects thymocytes from programmed cell death. J. Immunol. 148, 1817-1821 (1992).
35. O. Inanami, K. Sugihara, T. Okui, M. Hayashi, M. Tsujitani and M. Kuwabara, Hypoxia and etanidazole alter radiation-induced apoptosis in HL60 cells but not in MOLT-4 cells. Int. J. Radiat. Biol. 78, 267274 (2002).

36. Y. Dagon, S. Dovrat, S. Vilchik, D. Hacohen, G. Shlomo, B. Sredni, S. Salzberg and U. Nir, Double-stranded RNA-dependent protein kinase, PKR, down-regulates $\mathrm{CDC} 2 /$ cyclin $\mathrm{B} 1$ and induces apoptosis in non-transformed but not in v-mos transformed cells. Oncogene 20, 8045-8056 (2001).

37. A. Raghavan, R. L. Ogilvie, C. Reilly, M. L. Abelson, S. Raghavan, J. Vasdewani, M. Krathwohl and P. R. Bohjanen, Genome-wide analysis of mRNA decay in resting and activated primary human T lymphocytes. Nucleic Acid Res. 30, 5529-5538 (2002).

38. J. Yu, W. K. Leung, M. P. Ebert, E. K. Ng, M. Y. Go, H. B. Wang, S. C. Chung, P. Malfertheiner and J. J. Sung, Increased expression of survivin in gastric cancer patients and in first degree relatives. $\mathrm{Br}$. J. Cancer 87, 91-97 (2002).

39. T. S. Griffith, J. M. Fialkov, D. L. Scott, T. Azuhata, R. D. Williams, N. R. Wall, D. C. Altieri and A. D. Sandler, Induction and regulation of tumor necrosis factor-related apoptosis-inducing ligand/Apo-2 ligand-mediated apoptosis in renal cell carcinoma. Cancer Res. 62, 3093-3099 (2002).

40. D. S. O'Connor, J. S. Schechner, C. Adida, M. Mesri, A. L. Rothermel, F. Li, A. K. Nath, J. S. Pober and D. C. Altieri, Control of apoptosis during angiogenesis by survivin expression in endothelial cells. Am. J. Pathol. 156, 393-398 (2000).

41. Y. Shimamoto, K. Koizumi, H. Okabe, H. Kazuno, Y. Murakami, F. Nakagawa, A. Matsuda, T. Sasaki and M. Fukushima, Sensitivity of human cancer cells to the new anticancer ribo-nucleoside TAS-106 is correlated with expression of uridine-cytidine kinase 2. Jpn. J. Cancer Res. 93, 825-833 (2002).

42. K. Koizumi, Y. Shimamoto, A. Azuma, Y. Wataya, A. Matsuda, T. Sasaki and M. Fukushima, Cloning and expression of uridine/cytidine kinase cDNA from human fibrosarcoma cells. Int. J. Mol. Med. 8, 273-278 (2001).

43. Y. Maehara, H. Nakamura, Y. Nakane, K. Kawai, M. Okamoto, S. Nagayama, T. Shirasaka and S. Fujii, Activities of various enzymes of pyrimidine nucleotide and DNA syntheses in normal and neoplastic human tissues. Gann 73, 289-298 (1982). 